UDC 821.111(73):82-1:81'367

DOI https://doi.org/10.24919/2308-4863/42-3-31

Natalia SHEVELOVA-HARKUSHA, orcid.org/0000-0002-1440-5098

Candidate of Philological Sciences, Associate Professor at the Department of English for Maritime Officers

Kherson State Maritime Academy (Kherson, Ukraine) natalishg50685@gmail.com

\title{
FLIPPED CLASSROOM METHOD FOR TEACHING MARITIME ENGLISH
}

The article is devoted to a flipped classroom as an element of blended learning which is the reverse form of a traditional classroom study. First it was widely embraced and successfully adopted by the American and European pedagogical communities and now it is being more often considered in the studies of the Asian universities. The article aims at contributing to the field of flipped classroom research by briefly examining and analyzing the outcomes of the experiment conducted at many foreign universities within the course of English for specific purposes. It describes the principal components of a flipped learning and the way to successfully implement it in a class.

The flipped classroom has been defined as a pedagogical model in which the typical lesson and homework elements of a course are reversed and the way of providing content is also reversed. The idea of the method implementation with the main peculiarities of the flipped learning are regarded in details in this article. Unlike traditional ways, this method implies that students study new material or content at home on their own. The types of activities can be manifold, made in the form of short video lectures, tutorials, grammar, vocabulary, text-based tasks and other e-learning materials.

There are some rapid-learning tools which can be used by all teachers while teaching Maritime English. Moreover, such things as audio or video tutorials, smartphone apps or e-learning platforms enrich the learning environment as well as engage and motivate students to work more diligently.

The fact that students do out-of-class activities prior to the lesson allows teachers to organize in-class sessions much better in an effective way. As ESL learners get acquainted with new materials prior to the class session, the lesson becomes more practice-oriented.

Outlining several challenges, the author concludes on the significant benefits of the flipped classroom in ESL teaching, including an increase in students' overall performance on the course, enhancement of students' motivation and improvement of their autonomous learning and communicative skills.

Key words: a flipped classroom, blended learning, in/out-of-class activities, e-learning materials, gamification, quizzed activities.

Наталя ШЕВЕЛЬОВА-ГАРКУША, orcid.org/0000-0002-1440-5098 кандидат філологічних наук, дочент кафедри англійської мови з підготовки морських фахівців за скороченою програмою Херсонської державної морської академії (Херсон, Украӥна) natalishg50685@gmail.com

\section{ВИКОРИСТАННЯ МЕТОДУ «ПЕРЕВЕРНУТИЙ КЛАС» У ПРОЦЕСІ ВИКЛАДАННЯ МОРСЬКОЇ АНГЛІЙСЬКОЇ МОВИ}

Стаття присвячена методу «Перевернутий клас», який є елементом зміманого навчання, щзо має зворотну форму в організації порівняно з традиційним навчанням в аудиторії. Спочатку цеей метод був поширений та успішно прийнятий американською та європейською педагогічною спільнотою, а тепер його все частіше розглядають у дослідженнях азіатських університетів. Стаття має на меті зробити внесок у дослідження ефективності використання прийому, вивчити й проаналізувати результати експериментів, проведених у багатьох іноземних університетах у рамках курсу англійської мови за професійним спрямуванням. У статті зазначені основні компоненти «перевернутого навчання» та спосіб його успішної реалізації в межах навчальної аудиторії.

Цей метод визначений як педагогічна модель, у якій типові уроки й елементи домашнього завдання курсу змінюються, а спосіб практичного виконання завдання та виклад нового матеріалу взаємозамінюються. Ідея впровадження методу з основними особливостями перевернутого навчання детально розглянута в статті. На відміну від традиційних способів, ией метод передбачає, щзо студенти самостійно вивчають новий матеріал удома. Види діяльності можуть бути різноманітними: у формі коротких відеолекцій, навчальних посібників, граматичних завдань, словникового запасу, текстових завдань та іниих матеріалів для електронного навчання.

Існують деякі електронні інструменти для дистаниійного навчання, якими можуть користуватися викладачі під час викладання морської англійської мови. Більше того, такі речі, як аудіо-чи відеоуроки, програми для смарт- 
фонів або платформи електронного навчання, збагачують навчальне середовище, а також залучають $і$ мотивують студентів старанніше прачювати. Той факт, щьо учні виконують позаурочну діяльність до уроку, дає змогу вчителям ефективніше організовувати свої уроки. Оскільки студенти ознайомлюються з новими матеріалами перед уроком, то сам урок стає більш орієнтованим на практичне його використання й закріплення.

Окреслюючи особливості ичього методу, автор робить висновок про значні переваги «перевернутого навчання» для студентів вищих навчальних закладів, які передбачають збільшення загальної успішності студентів на курсі, підвищення мотивачї студентів і вдосконалення їхніх навичок самостійної роботи в навчанні, а також навичок активного спілкування та вільної комунікації.

Ключові слова: «перевернутий клас», змішане навчання, аудиторні/позааудиторні завдання, матеріали для електронного навчання, гейміфікація, завдання з тестуванням.

Problem statement. Proficiency in Maritime English consists in a substantial lexical basis. Indeed before a mariner can effectively communicate in maritime English, he/she needs to learn (i.e. memorize) a significant number of new words. Ship parts, standard position indicators, or VHF pro-words, for example, make up a whole new vocabulary, which must be learnt before being able to re-use it in sentences compliant with the very specific SMCP grammar (Ferreira, 2015: 73).

Research analysis. According to the last research works, a conventional so-called "chalk-talk method" which is used by many teachers to teach students nowadays has been revealed as impractical and inefficient by its poor results. That's why modern methodologists, such as J. Bergmann, A. Sams, A. Ash, B. Heterick, C. Twigg, K. A. Meyer and many others propose contemporary pedagogical method called "Flipped Classroom" or "Flipped Learning" to be used during a teaching process. This method is presented as the newest trend in teaching which is being used in numerous European and American colleges and universities today (Zainuddin, Halili, 2015: 15-16).

The purpose of the article is to give the definition to the method of a flipped blending learning; to reveal its specific features and peculiarities in details; to compare a flipped classroom method to a conventional so-called "chalk-talk method"; to determine in- and out-of-class activities used for providing a blending learning for ESL in higher educational establishments.

\section{The main part of the review}

Aflipped classroom is a blended learning teaching model which aims to increase student engagement and learning due to specific out-of-class activities, text-based asynchronous Internet technology and face-to-face communication (Garrison, 2004: 96).

Flipped classrooms focus on active learning and student engagement giving the instructor a better opportunity to deal with groups of students who have mixed level of knowledge and differentiated acquired skills (Melendez, 2017: 236).

The term "flipped" in this method of teaching is determined by a teaching procedure which, due to its uniqueness, takes place in a flipped (upside down) or inverted manner. The flipped classroom has been defined as a pedagogical model in which the typical lesson and homework elements of a course are reversed and the way of providing content is also reversed (Zainuddin, Halili, 2015: 15).

To grasp the idea of the method the following peculiarities of the flipped learning should be regarded in details:

\section{Personalized approach of teaching students.}

Unlike traditional ways, this method implies that students study new material or content at home on their own. According to the flipped learning they should explore digitized lesson materials using all their modern technical resources at home. Using the platform Moodle, for example, teachers are able to upload all tasks and provide students with new tutorial material to let them scrutinize it by themselves prior to each lesson in an in-depth manner (Zainuddin, Halili, 2015: 17).

The definite advantage of this method is that cadets can pass all the tasks and activities at their own pace. They can listen to videos, read texts, pronounce, imitate words and word-combinations as many times as they need to study the material thoroughly for deep and meaningful understanding (Ash, 2012: 24).

\section{Different types of interactive out-of-class activ-} ities.

The types of activities can be manifold, made in the form of short video lectures, tutorials, grammar, vocabulary, text-based tasks and other e-learning materials. But it's not only about creating simple theoretical video lectures and asking students to study some grammar points. It's preferable to use audio or video materials together with some power-point presentations.

Thus, the new vocabulary can be pronounced and explained in details by a teacher. The new learning information can be totally voiced by a teacher or some other native speaker (Zainuddin, Halili, 2015: 19).

Some quizzed activities and different sorts of "gamification" can also be elaborated by a teacher to let students pay an over-close attention to the new learning material in an intriguing and gaming manner. 
Though preparing materials for flipped classroom is a time-consuming task, which requires the sheer amount of work to implement this teaching strategy, it will make play (Ferreira, 2015: 74).

An effective flip requires careful preparation. Recording lectures demands a lot of effort and time. Out-of-class and in-class elements must be carefully integrated for students to help them understand the model and prepare for the next lesson. As a result, introducing a flip can mean additional work and may require new skills for the instructor, although this teaching method will give students an assist with active language study (Seven things about flipped classrooms, 2012: Web-site).

Online quizzes or activities can be interspersed to test which students need to pass and accomplish. Immediate quiz feedback and the ability to rerun lecture segments may help clarify points of confusion (Seven things about flipped classrooms, 2012: Web-site).

\section{Rapid-learning tools.}

There are some rapid-learning tools which can be used by teachers while teaching Maritime English:

1.1. MarEng and MarEngPlus Learning Tool are a web-based Maritime English learning tools. They are based on the idea of a virtual presence on a ship which is on voyage from port to port in Europe. During the voyage the crew of the ship faces a number of routine and exceptional situations in which Maritime English is used both on board and in port operations. Material is suitable for different language levels and is grouped in thematic modules. All of the material is based on language used in actual situations on ships, in ports, in shipping companies and elsewhere in the shipping chain. The MarEng(Plus) material can be used online out of the classroom, in distance learning and for self-study purposes (Rapid-learning tools, 2021: Web-site).

1.2. SeaTALK presents a unique online platform for Maritime English resources on the page http:// www.seatalk.pro. The platform provides a Maritime English syllabus with materials within a framework of STCW competences, CEFR levels and the ECVET system.

The SeaTALK platform offers Maritime English Training Modules for each rank and function on board: Deck Ratings (Support Level), Engineering Ratings (Support Level), Deck Officers (Operational Level), Engineering Officers (Operational Level), Electro Technical Officers (Operational Level), Senior Deck Officers (Management Level), Senior Engineering Officers (Management Level) and so on (Rapid-learning tools, 2021: Web-site).

Among other web-based tools for General English learning there are: Anki, Cleverlize, Edpuzzle, Edu- creations, gFlash+, The Mnemosyne Project, Multimedia Learning Object Authoring Tool, Nearpod, Quizlet, Socrative, Vocabulary Memorization Platform and so on (Ferreira, 2014: 86).

There are also some E-learning authoring tools which allow teachers to create e-learning products of professional quality with every possible type of quiz, learning interaction and learning games one can imagine (Heterick, Twigg, 2003: 28).

For example, iSpring suite 7 is a professional e-learning authoring suite. It integrates into PowerPoint to convert slideshows into interactive learning objects. It includes tools for animation, for screencasting, many different types of interactions and quizzes, and is fairly easy to learn. iSpring Suite 7 includes QuizMaker, a very versatile and powerful quiz generator, which can export to Flash ${ }^{\mathrm{TM}}$, HTML5, and SCORM format, thus ensuring seamless integration into most Learning Management Systems and portability to mobile devices (Ferreira, 2015: 78).

\section{Engaged and motivated students.}

This method of learning ensures that students will have more exposure to the language outside the classroom. Moreover, such things as audio or video tutorials, smartphone apps or e-learning platforms enrich the learning environment as well as engage and motivate students to work more diligently (Heterick, Twigg, 2003: 28).

\section{Distant control of a teacher.}

The way how students prepare themselves, the amount of their test probes, their final results and the most frequent mistakes can be monitored by teachers any time. Thus, teachers can monitor student's individual progress at all stages. Moreover, Internet communication tools provides participants with the possibility to write messages to their teachers every time they confront questionable ideas and have doubtful or faulty thinking while working online on a platform (Garrison, 2004: 99).

Teachers can answer and apply corrective measures individually for each student in need. Every teacher can send a personal message to those students who are lagging behind the group, which is enough to get them back with the class. This will ensure and engender commitment for students to do all the tasks on time (Kvashnina, Martynko, 2016: 73).

A teacher can also send a message in a group every week to announce the availability of new online learning material, so as to keep students' motivation high. In retrospect, this close monitoring and frequent communication with both the group and individual students in difficulty is probably the most important ingredient for the success of the online course on Moodle (Ferreira, 2014: 98). 


\section{An effective lesson time management.}

A flipped classroom is a very time-saving method because out-of-class activities free up classroom time for meaningful interaction of students who can do more productive oral activities in contrast to the usual lesson (Ferreira, 2015: 74).

The in-class time is devoted to hands-on exercises, projects or discussions as the basic in-class assigned activities, that create an environment where students can practise new language skills that they worked on at home freely.

\section{A prolongated production stage.}

The fact that students do out-of-class activities prior to the lesson allows teachers to organize in-class sessions much better in an effective way. As ESL learners get acquainted with new material before the class session, the lesson becomes more practice-oriented. That means that during the lesson the teacher is focused more on production stage, motivating students to use new language structures and engage them in the content.

Among the most common and efficient activities for production are:

1) Question-answer activity. This is the simplest form of interactive teaching tool, that can help students promote active learning, improve speaking skills and gauge up level of their knowledge, interest and comprehension (Meyer, 2003: 56).

2) Brainstorming. It is preferable to use brainstorm at the beginning of a lesson while presenting a new topic or at the end of a lesson as review.

3) Quescussion. A teacher can spice up conversations by challenging students to discuss a topic using only questions. The teacher starts the quescussion by providing a trigger. S/he kick-starts the discussion, ensures the question is visible to students either by slide display or written on the board. The stimulus might be a problem to be solved, a provocative question or statement, some text or a key word, a video clip, a multimedia presentation, or a website to be analysed or discussed (Paulson, Faust, 2021: 13).

This activity follows an informal discussion model, so students can shout out replies as they think of them. A statement disguised as a question which does not have to be directly related to the previous question (Center for Teaching Excellence, 2021: Web-site]. For example, "small holds are better than large ones, aren't they?". All questions are recorded, grouped, and used to determine and understand a specific topic better.

4) Debates. To implement this method in the classroom, a teacher should divide participants into large groups representing broad positions and controversial view points (Kvashnina, Martynko, 2016: 73). The activity can be broken down into two or three rounds. During the first round one team presents "Pro/positive" or "Arguments for" (10 minutes). After that the second team presents "Con/negative" or "Arguments against" (10 minutes).

Then teams are allowed to prepare their next responses ( 5 minutes) before the second and the third round. At the end of the debate during the whole class discussion other group of students determine which team provided the most convincing arguments. This could be done through a simple vote or a more detailed evaluation form (Center for Teaching Excellence, 2021: Web-site).

5) Flash Cards. A teacher or a student asks the question, while all cadets have to choose and raise green, red or yellow card if they agree, disagree or hesitate about some point respectively. Then they are grouped with regard to a chosen colour of a card and discuss their replies within a group. When the next question is given, the students are regrouped again to discuss it (Paulson, Faust, 2021: Web-site).

6) Think-Pair-Share/Think-Pair-Square-Share. It is a quick and easy method of engaging students in a collaborative activity. In think-pair-share the instructor proposes a difficult open-ended question or a note card to fill to the class. The students are asked to think about the question for a minute and then form into pairs or a group of four to discuss their views (Center for Teaching Excellence, 2021: Web-site).

7) Fishbowl. In a fishbowl discussion, a small group of students sit in the middle of the room, forming the "fishbowl" group. The rest of the class sits on the "outside." The group in the fishbowl can watch some video, read some text or have a look at some pictures. Then these students will be given an openended or "yes/no" questions by others. The outside group takes notes and analyze given replies. The class will then be asked as a whole to discuss what they have understood. The fishbowl technique helps students practice group discussion skills as well as active listening and note taking. This will accustom students to collaborative activities (Paulson, Faust, 2021: Web-site).

Thus, a flipped learning makes class time more student-centered through active learning techniques. This method creates a quality learning environment and ensures a dynamic and meaningful educational experience where the focus is not on a separate constructing knowledge, but on a real-life practice of skills and knowledge already acquired (Garrison, 2004: 99).

\section{8 . The role of a teacher-instructor.}

All the in-class activities are done under the close control of their teacher-instructor. The function of a 
teacher is to direct students and aid them with the most flummoxed and embarrassing moments in the learning process during the lesson. Among the most principal functions of a teacher-instructor are the following:

- to favour respondents with complex answers while they cross-examine each other. A teacher or a student must ask only one question at a time, as all the instructions and questions tend to be brief, accurate and logically clear;

- to allot some definite time to each activity and enforce it rigidly;

- to use a prompt that asks for tentative responses rather than declarative statements. For example, "What do you know, have heard, or have read about this topic?" This allows students to offer responses without having to fear being "wrong";

- accept students' input and ask somebody to organize it into logical groupings, if relevant, and make a brief summary after brainstorm or some discussions (Meyer, 2003: 55-56).

\section{Confident collaborative environment.}

Students work on live problem-solving tasks with face-to-face activities practising the new material in pairs and groups. During the collaborative work students feel rather confident, freely and unreservedly. As such, discussions are often more thoughtful, reasoned and supported by evidential sources (Meyer, 2003: 57).

This method is essential to move students to higher levels of thinking. Spontaneous and contagious faceto-face discussions make students work with full energy and enthusiasm and be verbally quick and assertive. It is essential for facilitating critical, creative and complex thinking skills. The critical thinking will move through exciting topics for discussion and discernible phases while an exploration, integration and application of a studied material (Garrison, 2004: 99).

\section{Improved results of students' academic achievements.}

Academics have found that flipped classroom in ESL teaching make students more confident and prepared for productive activities, pair work and simulated conversations. It is stated that students has significantly better results, almost $30 \%$ higher, when the flipped model was applied (Kvashnina, Martynko, 2016: 73).

The in-class test results were excellent and, more importantly, the orals were beyond teachers' expectations. All students passed the oral exam, including the foreign students. When teachers took the group to the bridge simulator, at the end of the course, they did the tasks very well despite the added stress of real-time movement and watchkeeping (Ferreira, 2014: 95).

Other outcomes achieved by the redesigns include increased course completion rates, improved retention, better student attitudes toward the subject matter, and increased student satisfaction with the mode of instruction compared to traditional formats.

In the studies reviewed by Heterick B. and Twigg C., typically, a large enrolment course replaces one or two lectures each week with any combination of online discussion groups, simulations, discovery labs, multimedia lessons, tutorials, assignments, research projects, quizzes and digital content.

These may be effectively facilitated by teaching assistants under the supervision of a professor. The professor has more time to give to individual students and enhance the quality of the course through sustained course development and innovation as well as teaching development (Heterick, Twigg, 2003: 28).

\section{Conclusions.}

1. There is evidence that blended learning has the potential to be more efficient when compared to a traditional classroom model. It is highly recommended for higher education institutions to transform syllabus of the English course in a manner of flipped classroom as an effective element of blended learning.

2. Flipped classroom allows students to acquire more independent learning culture and be as "a personal tutor". They can get acquainted with theoretical material at home, study a new language on their own, watch some videos and accomplish all tasks and activities at their own pace. This will permit them to assimilate the material thoroughly in a much more efficient way.

3. The academic benefit, evidence and competitive advantages are clear. The flipped model puts more of the responsibility for learning on the shoulders of students while giving them greater impetus to experiment and work at home. Due to this lessons of English will be student-led; and pair/group communication of students will become more productive, fluent, free and natural while active learning and speaking through hands-on work and interactive challenging tools.

The use of flipped classroom model for certain parts of the course syllabus throughout a semester will allow a significant increase in students' performance on the course, enhancement of students' motivation and improvement of their autonomous learning skills. Thus, we can conclude that the examined approach can be applicable and is beneficial not only for lecture-based courses but for ESL teaching as well. 